\title{
Geoscience Education in an Irish Context: A Need for Research
}

\author{
Emer Emily Neenan, Joseph Roche \\ School of Education, Trinity College Dublin, Dublin, Ireland \\ Email: neenane@tcd.ie
}

Received 29 April 2016; accepted 4 June 2016; published 7 June 2016

Copyright (C) 2016 by authors and Scientific Research Publishing Inc.

This work is licensed under the Creative Commons Attribution International License (CC BY). http://creativecommons.org/licenses/by/4.0/

(c) (i) Open Access

\begin{abstract}
Perception and understanding of geoscience in Ireland by non-geoscientists have not been studied in depth, and an improvement in understanding how geoscience is perceived and engaged with will have significant impact on Ireland's ability to meet a range of challenges, including hotly debated geoscience issues such as fossil fuel dependency, raw mineral management, water security, and shale gas extraction (particularly fracking). Geoscience plays an important role in society, and the understanding of geoscience of an average Irish person will be based on formal education (at primary and secondary level) and informal education through public outreach and news media. Geoscience is expanding in formal education and informal education is increasingly delivered online. Geoscience education in Ireland has not been studied in detail, and a better understanding of the state of geoscience education could improve connections between geoscientists and nongeoscientists. This paper discusses the scope of potential research into geoscience education in Ireland that could and should be undertaken in order to best understand and describe the state of geoscience education, and geoscience in society. Mixed-method research should be undertaken to study geoscience education at multiple levels and targeting multiple publics. This research into the state of geoscience education in Ireland would be valuable, to geoscientists and educators.
\end{abstract}

\section{Keywords}

Geoscience Education, Scientific Literacy, Geoscience in Society, Geoscience Outreach, Ireland

\section{Introduction}

Geoscience is vital for modern society; most particularly since all our energy sources, technologies, and amenities rely to a greater or lesser extent on the extraction and management of natural resources. The constituents of a modern mobile phone_-metals, rare earth elements, plastic (from petroleum) —and the electricity powering it-delivered by copper wire, and most likely generated from oil or gas-are all taken from the earth. As indi- 
viduals, it is not necessary to have a full understanding of all the geoscience behind our smartphone, any more than we need to understand the physics or electrical engineering behind it, but as a society, it is necessary to have a certain level of geoscientific literacy and to produce a certain number of geoscientists [1].

Ireland can only benefit from having a strong foundation in geoscience education, at all levels of the formal education system as well as in informal education such as via outreach programs, social media and news media. This is both specifically so Ireland produces a sufficiency of graduates in geoscience fields, and more generally so that Irish society can meet the energy and resource challenges of the 21st century. In order to achieve this, geoscience education in Ireland must be understood; yet so far, little research has been done to investigate either formal or informal education in geoscience in an Irish context.

Geoscience education in Ireland must be studied, in order to identify its strengths and weaknesses, so that strengths can be consolidated and expanded, and weaknesses can be monitored and minimised [2]. Research should be conducted into the content and efficacy of both formal and informal education in geoscience, identifying the actual learning outcomes across a broad cross-section of Irish society, from primary-school children, to consumers of news media, to politicians. The place of geoscience in the formal education system - particularly at primary and secondary school—should be examined. This is an especially important in light of the introduction of the new Junior Certificate Science curriculum which includes Earth Science as part of one of the core modules for secondary school students aged 12 to 14 [3]. Alongside formal education, informal geoscience education in Ireland should also be studied. This should include geoscience outreach programs and public engagement-traditional and online—by geoscience institutions and geoscientists [4], and should also include dissemination of geoscientific information via the news media.

The objective of this paper is to provide an outline of the current state of geoscience education in Ireland, demonstrate that the area needs to be more thoroughly researched, and propose how such research may be carried out. This research would aim to provide valuable information to geoscientists on how best to communicate their field; to third-level institutions on how to attract students into the geosciences; and to educators on how geoscience is currently being taught, and the strengths and weaknesses of the current system.

\section{The Place of Geoscience in Irish Society}

Geoscience plays a major role in society: globally, in the EU, and in Ireland. Geoscience underpins our energy sources, our management of natural resources (including fossil fuels, minerals and metals, water, etc.) [5] and our natural disaster planning [6]. Qualified geoscientists are necessary for energy security; security of the water supply; economic security for many industries; and security of the population in the event of a range of natural disasters, from minor landslides to catastrophic earthquakes.

The European Commission's Horizon 2020 framework identifies "Science with and for Society" as an instrumental area in addressing the challenges facing EU countries over the coming years [7]. These challenges include hotly debated geoscience-heavy issues such as fossil fuel dependency, raw mineral management and shale gas extraction (particularly fracking), mainly under the "Secure, Clean and Efficient Energy" umbrella [8].

Ireland is rising to meet these challenges. In 2014, the Irish Centre for Research in Applied Geosciences (iCRAG) [9] was established, funded by Science Foundation Ireland and the European Regional Development Fund, with the aim of ensuring the security and proper management of Ireland's natural resources [9].

Geoscience plays a substantial role in Ireland's economy and society and lies at the heart of a range of questions facing the Irish electorate. Ireland imports the majority of its energy [5], but has offshore hydrocarbon resources: Ireland is home to "untapped hydrocarbon resources in challenging north-eastern Atlantic deep water environments, and a diverse geological framework with important untapped seabed and groundwater resources" [9]. How to tap these resources is a question for Irish-based geoscientists; whether to tap them and how the output and profit is divided is a question for policy-makers. Ireland supports a range of mining activity; minerals, including metal ores, and rocks are mined across Ireland. Certain Irish rocks are sought-after as building materials, such as Connemara marble and Kilkenny limestone. The largest zinc mine in Europe is in Co. Meath, and produced 133 kilotonnes of zinc in 2015, along with smaller amounts of lead and silver [10]. Water is currently a contentious issue in Ireland, with decisions being made about how to maintain and manage the drinking water supply, and how that should be paid for [11]. There is also an ongoing discussion about how best to protect Ireland's unique ecosystems [12]. It is not unreasonable to suggest that an understanding of geoscience would be of benefit to politicians, civil servants and the electorate. 
Of particular interest is the contentious issue of shale gas extraction by means of hydraulic fracturing (fracking), which may be an economically valuable source of hydrocarbons in energy-poor Ireland, but has stirred controversy due to the threats of induced seismicity and damage to ecosystems and water supplies [13]. The level of understanding of the geoscience of fracking - of policy-makers, the electorate, locals in areas where fracking is taking place, and the news media-is based on their levels of geoscience literacy from formal education, and the efficacy of informal education undertaken by geoscientists who are involved with fracking, researching fracking, or who are interviewed on the topic, and the information presented by the news media. Perceptions and attitudes by non-geoscientists towards fracking have been studied elsewhere, such as in the UK [14], but the perceptions, attitudes and understanding of non-geoscientists in Ireland have not yet been studied.

\section{Geoscience Education in Ireland Is Changing}

Geoscience has not historically been prioritised in the formal education system in Ireland, and has also not been studied in an Irish context. An overview of the current state of affairs is presented in this section.

In the primary school system (ages 4 to 12), some geoscientific concepts are covered under the Social, Environmental and Science Education (SESE) umbrella [15], which includes science, geography and history. However, geoscience or geology are not specifically covered in the curriculum and science is allocated only 45 minutes (at ages 4 to 6 ) to one hour (at ages 6 to 12) per week, which is only slightly more than is allocated to calling the roll (50 minutes per week), and —as is often noted — considerably less than the time devoted to religious education (2 hours and 30 minutes per week) [16]. As geoscience must share an hour a week with the other sciences, it could be expected that the average Irish primary school pupil does not get much exposure to geoscience or geology.

The geosciences are given more attention in the secondary school system (ages 12 to 18), however, geology is not a subject offered at Junior or Leaving Certificatelevel. Areas of geoscience, including geology, are covered as part of the Geography and Science subjects at Junior Certificate level (ages 12 to 16) [17]. At Leaving Certificate level (ages 16 to 18), Geography is still offered and includes several areas that fall under the broader geoscience umbrella, such as some geological concepts. Meanwhile, Science is no longer offered as a single subject at Leaving Certificate level; instead it breaks into specific science subjects (Physics, Chemistry, Physics and Chemistry, Biology, Agricultural Science), and again, Geology is not an offered subject [18].

At third level, Geology is established as a stand-alone subject and geoscience has a significant place at undergraduate and postgraduate level in four of Ireland's seven universities: Trinity College Dublin (offering Geology and Earth Science Bachelor's degrees, along with geoscience-adjacent subjects) [19], University College Dublin (offering Geology as a B.Sc., along with geoscience-adjacent subjects) [20], National University of Ireland Galway (offering Earth and Ocean Sciences, as well as geoscience-related subjects, as B.Sc. Degrees) [21], and University College Cork (Geology, Earth Science and International Field Geoscience all offered at Bachelor's level) [22]. All of these Geology/Geoscience courses are taken as specialties in later years from a common-entry broader science course. For example, in Trinity College Dublin, students who study geology enter Natural Sciences, taking modulesin multiple sciences, including geology, in their first and second year, and specialise in geology for their third and fourth, to graduate with a Bachelor's degree in "Natural Sciences-Geology". Geography and Environmental Science are also widely offered [23].

Geoscience education in Ireland is in a period of change. Postgraduate-level education is expanding, with initiatives such as iCRAG (mentioned above). The Junior Certificate state examination is being overhauled, and Science at Junior Certificate level will now include "Earth and Space" as one of its core "strands", giving geoscience a defined space within the core curriculum for the junior cycle of secondary level education [3].

As there have not been any published studies on geoscience in the formal education system in Ireland, it is not currently possible to explore it in greater depth.

\section{Research into Geoscience Education}

Science education in Ireland has been studied (albeit perhaps not as deeply as science education researchers would prefer), but geoscience education specifically has not been studied in detail in Ireland. For example, in 2003, Ireland took part in the Relevance of Science Education (ROSE) project, which gauged a range of factors relating to science education in 15/16-year-old Irish students, but only a few questions in the survey related directly to geoscience and geoscientific principles [24]. 
Geoscience education—formal and informal—has been studied elsewhere. A good overview of the ongoing research in the area was carried out by King (2008) [25]. There is a very broad range of potential research in the area; researching understanding, interest, perceptions and attitudes of primary-level, secondary-level and tertiary-level students, educators at all levels, participants in geoscience outreach programs, social media users, residents in areas where activities such as mining or fracking are planned or ongoing, and so on [25] [26].

Research into the efficacy of geoscience education focuses primarily on the understanding of and interest in geoscience of students in the formal education system, and the level of understanding of geoscientific principles of educators. Tools such as the Geoscience Concept Inventory [27] are used to measure the level of understanding of principles such as geological time and the location and scale of tectonic plates, and can be used to assess, for example, the level of understanding that teachers have of core geoscience concepts.

Outreach and public understanding are no longer minor side-projects for scientific institutions, and as global connectivity and social media expand, scientists-including geoscientists-have unprecedented opportunities to engage with enthusiasts, children, voters, locals and politicians [28]. However, engagement on social media is not always undertaken in an effective manner, and the efficacy of new online informal methods of education is an expanding area of research; for example, Lee \& Van Dyke (2015) assess how effectively science institutions are using social media to promote dialogue with interested publics [29].

\section{Need for New Insight into Geoscience Education in Ireland}

Geoscience education—formal and informal—in Ireland should be studied, ideally as broadly and deeply as possible. There will always be limits on the amount of research that can feasibly be done in an area, but so far very little work has been undertaken to assess the state of geoscience education in Ireland. Geoscience is an important and dynamic area, connected with several contentious issues in current Irish policy, and it would be illuminating and useful to know what the average Irish schoolchild, student, voter and inhabitant know and think about geoscience generally andabout key geoscientific concepts and issues, such as fracking. There is scope for a broad range of future research in this area.

\subsection{Study of Formal Education}

Research targeting a broad, representative sample of Irish schoolchildren or secondary school students-similar to the ROSE project-could gauge the interest and knowledge of the average Irish schoolchild with regard to geoscience [30]. The understanding of geoscience held by a person leaving the Irish education system is likely to be a strong contributing factor in the general level of understanding of the next generation of Irish voters and policy-makers.

In order for schools to provide a useful and engaging introduction to geoscience, primary school teachers and secondary school Science and Geography teachers need to be equipped to teach geoscience in an accurate and engaging manner. There is no requirement for these teachers to have formally studied geology or any other geoscience subjects at higher level themselves. If there are significant gaps in their understanding of the subject, they are likely to pass misunderstandings and misconceptions on to the students they teach [31]. They can be supported by, for example, outreach programs that operate through the formal education system, such as the Seismology in Schools program [32]. It would be very useful to explore such teacher supports and school-based outreach programs to assess their efficacy and penetration [33], with the aim of facilitating improvements.

Specifically, it would be useful to assess whether outreach programs that operate through the school system are more or less effective than those that operate independently. Independent programs will probably only reach children who already have an interest in geoscience, whereas school-based programs will result in exposure to all children, or all children who have chosen Science or Geography in secondary schools, regardless of interest (although it is probable that interested children will engage with the school-based program more enthusiastically than uninterested children, so the effect may be small) [34]. Evaluative summative research into existing outreach programs, both independent programs and programs connected to formal education, and formative research into the programs found to be the most effective and engaging, could lead to new frameworks and guidelines to maximise effectiveness and scope of geoscience outreach [34] [35].

Children tend to be very interested in geoscience (rocks and minerals, volcanoes and earthquakes) but, as with science generally, many of them lose this interest as they grow older [1]. Studies of students' level of interest in geoscience, involving multiple cross-sectional studies of selected age cohorts, may be able to determine at what 
point this loss of interest happens and what factors are at play. To extend this research, it would be useful to examine at what point the genders diverge in level of engagement with geoscience, and whether there are ways to prevent this divergence. According to the ROSE study, girls show higher levels of interest across the sciences, including on geoscience-related topics [24]. Yet-again reflecting general trends across the sciences-by the time those interested children have grown up and found jobs, the girls will have disproportionally left the field [36] [37].

\subsection{Study of Informal Education}

Informal education has been transformed by the Internet. Outreach programs and public engagement need no longer be restricted to the immediate area and designated, scheduled times. A child or adult with an interest in geoscience can watch videos, read descriptions, look at diagrams, and even ask questions of geoscientists, at their leisure from their homes [38]. And modern, online engagement hasn't replaced traditional outreach; school visits, public lectures, open days, etc., are not phased out when an institution starts putting information online, but instead can be enhanced and augmented by the online resources [39]. Research should be undertaken to explore geoscience outreach programs and public engagement policies in Ireland, with a view to identifying and sharing the most effective techniques for dialogue with interested publics. In order for Irish public understanding and engagement with geoscience to be promoted, it must be understood, and in order for geoscientists to communicate the importance of their field, they need information on how to do so effectively [29].

Research into outreach programs should identify their efficacy; particularly whether they typically reach their target demographics, and whether they significantly improve participants' knowledge of, interest in, and/or engagement with geoscience. Follow-up research (as mentioned above under formal education) could include formative research into the programs found to be the most effective and engaging, in order to produce guidelines and frameworks for other outreach programs to use [39].

A very modern facet of outreach is the use of social media, which can be used as a very effective dialogic tool for engagement with interested publics, but research has not been done to determine whether geoscience institutions in Ireland are using social media, and, more importantly, whether they are doing so effectively [29]. Geoscience blogs and social media pages could have a significant impact on public perception and engagement with geoscience, and this should be studied in an Irish context. Scientists are encouraged these days to share their knowledge and research with the public [40] [41], but this needs to be done in a useful way, otherwise it takes valuable time that would be better spent on the research itself. Irish geoscientists could benefit from a better understanding of how the Irish public reacts to and understands geoscience, if they are to share their knowledge [41].

A very particular form of education is education via the news media, which is itself undergoing a considerable shift as people increasingly consume news online rather than through traditional channels. A better understanding of how the Irish news media frames and reports on geoscience-related issues_particularly contentious politically-charged issues such as fracking-would be very useful for assessing how the news media impacts public perceptions of geoscience [42]. Geoscientists undertaking public education or who are being interviewed by the news media may also benefit from such research. It would potentially be illuminating to examine the language used by the news media (e.g. "man-made earthquakes” vs “induced seismicity”, "fossil fuels” vs "hydrocarbons", "tidal wave” vs "tsunami”) and perform content analysis of the language choices, to assess the impact they may have on the perceptions of geoscience of the average viewer or reader [43]. It is also important to examine who is given a platform to speak on geoscience-related issues to assess what biases might be at play and might be being passed on to viewers or readers; for example, a gender bias, or a bias for or against mining companies, or environmental groups, or academic researchers [44].

\subsection{Future Research}

Alongside an investigation into Irish geoscience education, it would be natural to examine the effects of education—formal and informal—on attitudes and policies. Even if it is not possible to definitively identify effects, an examination of correlations between level of education, level of understanding, and attitude would be very interesting, and potentially have usable implications for educators and policy-makers in the area. It would also be worth examining Ireland's place in an international context, for both geoscience education and attitude towards/understanding of geoscience [24]. Similarities and differences between Ireland and other countries could 
open further avenues of research and potentially help guide Irish geoscience education policy in the future.

There is also potential benefit in examining the level of geoscience education and understanding of the politicians and policy-makers who are legislating on issues like fracking, offshore hydrocarbon exploration, and water security. With geoscience playing a significant role in the Irish and global economies, it is important to know whether legislators are equipped to make decisions on these issues; to understand the implications of the choices and to access impartial and accurate information where necessary [45].

\section{Conclusions}

A better understanding of the state of geoscience education-formal and informal—in Ireland would be valuable for the geoscience community in Ireland and for Irish society generally. The strengths and weaknesses of geoscience education in Ireland should be identified so that Ireland can best meet the energy and resource challenges facing it.

There is a broad range of potential research in the area that could be undertaken. Studies of the current cohort of Irish primary- and secondary-school students with specific regard to geoscience should be undertaken to assess the understanding of and interest in geoscience of Irish schoolchildren and potential future geoscience graduates. If possible, the factors affecting the decisions by students not to pursue geoscience should be identified, particularly with regard to girls. Research into the efficacy of outreach programs-in and out of schools-and public engagement_-online and offline_-should be undertaken. Effective programs should be identified and studied with the aim of producing useful information for geoscientists on how to communicate their field. Geoscience as portrayed by news media should be examined, and an attempt should be made to determine the effect education via news media has on Irish people's attitudes towards geoscience-related current affairs issues, such as fracking and water security. Ideally, all of this research should be extended to examine the effects of formal and informal education in geoscience on perceptions of geoscience and, again, attitudes towards geosciencerelated issues.

In order to provide the most accurate overview of the state of geoscience engagement, mixed-method research should be carried out from multiple angles and targeting multiple publics [26]. A particularly good, but resource-heavy, study of geoscience in formal education would involve surveying multiple cohorts of students across primary and secondary school, and following up with the same students over a longitudinal study [24] [46]. Research into effective educational programs and techniques (either in formal education or outside it, and either traditional or online) could, to maximise usefulness, be undertaken in two phases: a summative phase to investigate whether programs or techniques are working as intended, and then a formative phase to determine what factors are responsible for the success of the most effective programs. This research should be quantitatively-led, but a mixed-method approach would allow potential insight from students, educators, etc., as participants in qualitative studies [47]. Content analysis could be a useful tool for research into both formal education (e.g. content analysis of textbooks) and informal education (e.g. content analysis of social media posts by geoscience institutes engaging in public outreach) [48].

A better understanding of the current and evolving position of geoscience in the Irish education system and in Irish society can only improve the ability of geoscientists and educators to maintain and improve Ireland's good relationship with geoscience.

\section{References}

[1] Gonzales, L.M. and Keane, C.M. (2009) Who Will Fill the Geoscience Workforce Supply Gap? Environmental Science \& Technology, 44, 550-555. http://dx.doi.org/10.1021/es902234g

[2] Lewis, E.B. and Baker, D.R. (2010) A Call for a New Geoscience Education Research Agenda. Journal of Research in Science Teaching, 47, 121-129.

[3] An Roinn Oideachas agus Eolaíachta (2016) Junior Certificate Science Syllabus (Ordinary Level and Higher Level) [Syllabus]. http://www.curriculumonline.ie/getmedia/7deb12f9-0031-44e3-a7ae-482465572fcf/jc_science_03sy_rev_2008

[4] Andrews, E., Weaver, A., Hanley, D., Shamatha, J. and Melton, G. (2005) Scientists and Public Outreach: Participation, Motivations, and Impediments. Journal of Geoscience Education, 53, 281. http://dx.doi.org/10.5408/1089-9995-53.3.281

[5] Sustainable Energy Authority of Ireland (2014) Energy in Ireland: Key Statistics 2014. 
https://www.seai.ie/Publications/Statistics_Publications/Energy_in_Ireland/Energy_in_Ireland_Key_Statistics/Energy-i n-Ireland-Key-Statistics-2014.pdf

[6] Irish Landslides Working Group, Geological Survey of Ireland (2006) Landslides in Ireland. https://www.gsi.ie/NR/rdonlyres/829D5C0E-3E21-429F-88E3-82F899D11CA2/0/Landslidesin_Ireland.pdf

[7] European Commission (2016) Horizon 2020 Work Program 2016-2017: 16. Science with and for Society. http://ec.europa.eu/research/participants/data/ref/h2020/wp/2016_2017/main/h2020-wp1617-swfs_en.pdf

[8] European Commission (2016) Horizon 2020 Work Program 2016-2017: 10. Secure, Clean and Efficient Energy. http://ec.europa.eu/research/participants/data/ref/h2020/wp/2016_2017/main/h2020-wp1617-energy_en.pdf

[9] Irish Centre for Research in Applied Geosciences (2016) iCRAG: About. http://icrag-centre.org/about/

[10] Boliden (2016) Boliden Tara Mines. http://www.boliden.com/Operations/Mines/Tara/

[11] The Irish Times (2016) Q\&A: Will Fianna Fáil rue its stance on water charges? http://www.irishtimes.com/news/environment/q-a-will-fianna-f\%C3\%A1il-rue-its-stance-on-water-charges-1.2624210

[12] Environmental Protection Agency Ireland (2012) Ireland's Environment 2012-An Assessment. http://www.epa.ie/pubs/reports/indicators/00061_EPA_SoE_2012.pdf

[13] Howarth, R.W., Ingraffea, A. and Engelder, T. (2011) Natural Gas: Should Fracking Stop? Nature, 477, $271-275$. http://dx.doi.org/10.1038/477271a

[14] Williams, L., Macnaghten, P., Davies, R. and Curtis, S. (2015) Framing "Fracking”: Exploring Public Perceptions of Hydraulic Fracturing in the United Kingdom. Public Understanding of Science, 2015, 1-17. http://dx.doi.org/10.1177/0963662515595159

[15] National Council for Curriculum and Assessment (1999) Primary School Curriculum Science: Social, Environmental and Scientific Education [Curriculum]. http://www.curriculumonline.ie/getmedia/346522bd-f9f6-49ce-9676-49b59fdb5505/PSEC03c_Science_Curriculum.pdf

[16] INTO Website (n.d.). https://www.into.ie/ROI/InformationforMedia/InformationforJournalists/TimeSpentonEachSubject.pdf

[17] State Examinations Commission (2016) Description of Certificate Examinations: Junior Certificate. https://www.examinations.ie/?l=en\&mc $=\mathrm{ca} \& \mathrm{sc}=\mathrm{sC}$

[18] State Examinations Commission (2016) Description of Certificate Examinations: Leaving Certificate. https://www.examinations.ie/index.php?l=en\&mc=ca\&sc=sb

[19] Trinity College Dublin (2016) Undergraduate Courses: Sciences. http://www.tcd.ie/courses/undergraduate/subject/subjects.php?sub=SCI

[20] University College Dublin (2016) UCD Science Degree Courses. https://myucd.ucd.ie/courses/science.ezc

[21] National University of Ireland Galway (2016) Undergraduate Courses. http://www.nuigalway.ie/courses/undergraduate-courses/

[22] University College Cork (2016) Courses. http://www.ucc.ie/en/study/undergrad/courses/

[23] Central Applications Office (2016) Course Search (2016 Courses). http://www.cao.ie/courses.php

[24] Matthews, P. (2007) The Relevance of Science Education in Ireland. ROSE Project, Royal Irish Academy, Dublin.

[25] King, C. (2008) Geoscience Education: An Overview. Studies in Science Education, 44, 187-222. http://dx.doi.org/10.1080/03057260802264289

[26] Lewis, E.B. and Baker, D.R. (2010) A Call for a New Geoscience Education Research Agenda. Journal of Research in Science Teaching, 47, 121-129.

[27] Libarkin, J.C. and Anderson, S.W. (2006) Development of the Geoscience Concept Inventory. Proceedings of the National STEM Assessment Conference, Washington DC, 19-21 October 2006, 148-158.

[28] Stilgoe, J., Lock, S.J. and Wilsdon, J. (2014) Why Should We Promote Public Engagement with Science? Public Understanding of Science, 23, 4-15. http://dx.doi.org/10.1177/0963662513518154

[29] Lee, N.M. and Van Dyke, M.S. (2015) Set It and Forget It: The One-Way Use of Social Media by Government Agencies Communicating Science. Science Communication, 37, 533-541. http://dx.doi.org/10.1177/1075547015588600

[30] Osborne, J., Simon, S. and Collins, S. (2003) Attitudes towards Science: A Review of the Literature and Its Implications. International Journal of Science Education, 25, 1049-1079. http://dx.doi.org/10.1080/0950069032000032199

[31] Trend, R.D. (2001) Deep Time Framework: A Preliminary Study of UK Primary Teachers' Conceptions of Geological Time and Perceptions of Geoscience. Journal of Research in Science Teaching, 38, 191-221. http://dx.doi.org/10.1002/1098-2736(200102)38:2<191::AID-TEA1003>3.0.CO;2-C

[32] Seismology in Schools Ireland (n.d.) Seismology in Schools (Seismeolaíocht sa Scoil) Pilot Project. 
https://www.dias.ie/sis/index.html

[33] Denton, P. (2008) Seismology in Schools: 10 Years on. Astronomy \& Geophysics, 49, 6.13-6.14. http://dx.doi.org/10.1111/j.1468-4004.2008.49613.x

[34] Laursen, S., Liston, C., Thiry, H. and Graf, J. (2007) What Good Is a Scientist in the Classroom? Participant Outcomes and Program Design Features for a Short-Duration Science Outreach Intervention in K-12 Classrooms. CBE-Life Sciences Education, 6, 49-64. http://dx.doi.org/10.1187/cbe.06-05-0165

[35] Markowitz, D.G. (2004) Evaluation of the Long-Term Impact of a University High School Summer Science Program on Students' Interest and Perceived Abilities in Science. Journal of Science Education and Technology, 13, 395-407. http://dx.doi.org/10.1023/B:JOST.0000045467.67907.7b

[36] Holmes, M.A., O’Connell, S., Frey, C. and Ongley, L. (2008) Gender Imbalance in US Geoscience Academia. Nature Geoscience, 1, 79-82. http://dx.doi.org/10.1038/ngeo113

[37] Jasanoff, S. (2014) A Mirror for Science. Public Understanding of Science, 23, 21-26. http://dx.doi.org/10.1177/0963662513505509

[38] Geology Degrees (2016) Geology Online: 105 Sites That Rock. http://geologydegree.org/sites-that-rock/

[39] Varner, J. (2014) Scientific Outreach: Toward Effective Public Engagement with Biological Science. BioScience, 64, 333-340. http://dx.doi.org/10.1093/biosci/biu021

[40] Andrews, E., Weaver, A., Hanley, D., Shamatha, J. and Melton, G. (2005) Scientists and Public Outreach: Participation, Motivations, and Impediments. Journal of Geoscience Education, 53, 281-293. http://dx.doi.org/10.5408/1089-9995-53.3.281

[41] Stewart, I.S. and Nield, T. (2013) Earth Stories: Context and Narrative in the Communication of Popular Geoscience. Proceedings of the Geologists' Association, 124, 699-712. http://dx.doi.org/10.1016/j.pgeola.2012.08.008

[42] Smith, J. (2005) Dangerous News: Media Decision Making about Climate Change Risk. Risk Analysis, 25, $1471-1482$. http://dx.doi.org/10.1111/j.1539-6924.2005.00693.x

[43] Fowler, R. (2013) Language in the News: Discourse and Ideology in the Press. Routledge, Abingdon.

[44] Niemi, M.K. and Pitkänen, V. (2016) Gendered Use of Experts in the Media: Analysis of the Gender Gap in Finnish News Journalism. Public Understanding of Science, 1-14. http://dx.doi.org/10.1177/0963662515621470

[45] Hoppe, R. (1999) Policy Analysis, Science and Politics: From "Speaking Truth to Power" to "Making Sense Together". Science and Public Policy, 26, 201-210.

[46] Gibson, H.L. and Chase, C. (2002) Longitudinal Impact of an Inquiry-Based Science Program on Middle School Students’ Attitudes toward Science. Science Education, 86, 693-705. http://dx.doi.org/10.1002/sce.10039

[47] Johnson, R.B. and Onwuegbuzie, A.J. (2004) Mixed Methods Research: A Research Paradigm Whose Time Has Come. Educational Researcher, 33, 14-26. http://dx.doi.org/10.3102/0013189X033007014

[48] Lee, M.H., Wu, Y.T. and Tsai, C.C. (2009) Research Trends in Science Education from 2003 to 2007: A Content Analysis of Publications in Selected Journals. International Journal of Science Education, 31, 1999-2020. http://dx.doi.org/10.1080/09500690802314876 